Care: Jurnal Ilmiah Ilmu Kesehatan Vol .7, No.2, 2019, hal 61-68

Tersedia online di https://jurnal.unitri.ac.id/index.php/care

ISSN 2527-8487 (online)

ISSN 2089-4503 (cetak)

\title{
KAJIAN METODE PERSALINAN NORMAL DENGAN BANTUAN CERMIN PADA PERSALINAN KALA II IBU PRIMIGRAVIDA
}

\author{
Rokhamah,Qotimah \\ Akademi Kebidanan Wira Husada Nusantara Malang \\ E-mail : rokhamah179@gmail.com. \\ akbidwhnqotimah@gmail.com
}

\begin{abstract}
The success of labor is influenced by several factors, namely maternal factors (power, passage, psychology), fetal factors (placenta) and helping factors. Using mirror aids in the process of progress in labor at a second time can increase maternal motivation psychologically and emotionally, this preventing and or decreasing pathological labor prevalence. The purpose of this study was determining the difference in time in mothers who had labor in the second time using a mirror and who did not use a mirror. The design of this study used True - experiment with post test only Control design, the sample of study were 40 physiologically 20 primigraphic delivery mothers who were treated, 20 were not treated and taken randomly. The purpose of this study was determining the time difference in labor mothers when second uses a mirror and does not use a mirror. Observation data collection techniques, it used unpaired T test. This research was conducted in 2018 in the Poncokusumo Malang Health Center. The results showed that labor with the help of a mirror could accelerate the second stage of labor in primigravida mothers. This is evidenced by the average time used by maternity in group I (using mirrors) is 7.05 minutes and the average time used by group II maternity women (without using a mirror) is 16.15 minute. The use of a mirror aid can be used as an instrument complement labor in order to reduce maternal morbidity and mortality in Indonesia.
\end{abstract}

Keywords: Mirror; Primigravida labor; Second Period of Labour.

\begin{abstract}
ABSTRAK
Keberhasilan persalinan dipengarui berbagai macam-macam faktor diantaranya faktor ibu (power, passage, psikologi), faktor janin (plasenta) dan faktor penolong. Penggunaan alat bantu cermin dalam proses mempercepat kemajuan persalinan pada kala II dapat meningkatkan motivasi ibu secara psikis dan emosional, sehingga mencegah dan atau menurunkan prevalensi persalinan patologis. Penelitian ini bertujuan untuk mengetahui perbedaan waktu pada ibu yang persalinan kala II menggunakan cermin dan tanpa cermin. Dalam penelitian ini Desain yang digunakan True-eksperimen dengan posttest only Control design, dalam penelitian sampel yang digunakan $40 \mathrm{ibu}$ melahirkan primigrafida yang fisiologis 20 diberi perlakuan, 20 tidak diberi perlakuan dan diambil secara acak, Penelitian ini bertujuan untuk mengetahui perbedaan waktu pada ibu yang persalinan kala II menggunakan cermin dan tanpa cermin. Tehnik pengambilan data secara observasi Data dianalisa menggunakan Uji T test tidak berpasangan. Penelitian ini

Cara mengutip: Rokhamah. (2019). Kajian Metode Persalinan Normal dengan Bantuan Cermin pada Persalinan Kala II Ibu Primigravida. Care:Jurnal Ilmiah Ilmu Kesehatan, 7(2), 61-68
\end{abstract}


dilaksanakan pada tahun 2018 di wilayah Puskesmas Poncokusumo Malang. Hasil penelitian menunjukkan bahwa ibu ibu bersalin primigrafida yang menggunakan cermin pada persalinan kala II lebih cepat . Bisa kita lihat pada rata-rata waktu yang digunakan oleh ibu bersalin pada kelompok I (menggunakan cermin) adalah 7.05 menit dan rata-rata waktu yang digunakan oleh ibu bersalin kelompok II (tanpa menggunakan cermin) adalah 16.15 menit. Pemakaian alat bantu cermin dapat dimanfaatkan sebagai komplemen instrumen persalinan guna menurunkan angka morbiditas dan mortalitas ibu di Indonesia.

Kata Kunci : Cermin; Persalinan Normal kala II; Primigravida.

\section{PENDAHULUAN}

Proses Persalinan merupakan proses membuka dan menipisnya serviks dan janin turun kedalam jalan lahir. Persalinan dan kelahiran dikatakan normal apabila proses pengeluaran janin yang terjadi pada kehamilan cukup bulan (37-42 minggu), lahir spontan dengan presentasi belakang kepala , tidak disertai komplikasi baik ibu maupun janin (Hidayat, 2010). Keberhasilan persalinan dipengarui berbagai macam faktor diantaranya ( power, passage, psikologi), faktor janin (plasenta), dan faktor penolong.Faktor faktor ini perlu diperhatikan karena kematian ibu dan bayi disebabkan o'leh tidak terdeteksinya lebih awal dari faktor tersebut (Ai Nurasiah, 2014).

Power merupakan kekuatan yang membuat janin keluar yang meliputi his dan tenaga mengedan, his adalah kekuatan kontraksi uterus yang diakibatkan otot - otot polos rahim berkontraksi dengan sempurna, kontraksi -kontraksi uterus yang tadinya tidak nyeri berubah menjadi kontraksi kontraksi yang terkoordinir, nyeri, dangat efisien sehingga menyebabkan pembukaan cerviks dan pengeluaran bayi (Ai Nurasiah, 2014).

Ketika ada his maka akan timbul nyeri. Nyeri merupakan perasaan yang terasa tidak menyenangkan, sifatnya sangat subyektif dan perasaan nyeri berbeda pada setiap orang dalam hal skala atau tingkatannya, sehingga hanya orang tersebutlah yang dapat menjelaskan atau mengevaluasi rasa nyeri yang dialaminya (Musrifah \& A.Azis, 2008).

Nyeri dalam persalinan bisa menyebabkan stres yangmenyebabkan hormon katekolamin dan steroid keluar, hormon inimerangsang otot polos menjadi vasokontriksi dan tegang sehingga menyebabkan penurunan kontraksi uterus sirkulasi darah dari uterus ke plasenta sehingga impuls nyeri bertambah banyak dan meningkatkan rasa nyeri Niven \& 
Gijsbers, potter \& Ann Griffin dalam (Sri rejeki, 2014).

Menurut penelitian Nurlaila 2008 dalam (Anisah M, 2012) beberapa ibu memiliki kecenderungan untuk melakukan operasisesar walupun tanpa indikasi yang jelas, didapatkan data 13,9\% dilakukan persalinan perabdominal dan tidak mempertimbangkan dari segi medis dan persalinan perabdominal dikarenakan atas permintaan ibu sendiri, menurut mereka dengan melakukan operasi sesar akan terhindar dari nyeri.

Menurut (Cristine, H. \& Jone, 2006) dukungan dapat memberikan dampak yang positif dalam sebuah persalinan, dukungan ini dapat berupa dukungan fisik dan emosional, dukungan emosional dapat berupa ketrampilan komunikasi dan informasi dengan indera penglihatan. Upaya mempercepat waktu persalinan Kala II peneliti melakukan suatu tindakan yang dapat mempercepatya yaitu dengan menggunakan alat bantu cermin dimana ibu ddeniberi kesempatan untuk melihat keadaan perkembangan keluarnya bayinya sehingga membangunkan tingkat emosional ibu sehingga memberikan dukungan melalui indera penglihatan.

Persalinan di Puskesmas Poncokusumo dalam 3 bulan terakhir terdapat 55 yang terdiri dari primipara multipara dan grandemulti berdasarkan study pendahuluan pada bulan Mei terdapat 13 ibu Inpartu yang mengatakan nyeri terutama pada saat akhir (kala II), dekat dengan rumah peneliti. Dengan melihat kepala bayi diharapkan menambah semangat ibu untuk mengejan sehingga akan mempercepat kala II, Nyeri dalam persalinan bisa menyebabkan stres yang akhirnya hormon katekolamindan steroid terlepas sehingga otot polos menjadi tegang dan pembuluh darah menjadi vasokontriksi dan terjadi penurunan kontraksi uterus dan membuat persalinan kala II lebih lama , persalinan lama bisa menyebabkan aspeksia pada bayi dan perdarahan pada ibu, kelemahan bila ibu takut dengan darah bisa menyebabkan penurunan tekanann darah oleh karena itu hanya diberikan pada ibu yg tidak takut dengan darah.

Berdasarkan inilah maka penulis perlu melakukan penelitian tentang perbandingan waktu melahirkan yang diberi cermin dan yang tidak diberi cermin karena salah satu faktor yang mempengarui persalinan tergantung dari emosional atau psikis ibu. Untuk itu judul penelitian ini yaitu Kajian persalinan normal dengan cermin pada ibu bersalin kala II Primigravida Di Puskesmas Poncokusumo Malang”. 


\section{METODE PENELITIAN}

Materi dalam penelitian ini adalah:

1) Menyiapkan cermin yang diberi bingkai dengan ukuran panjang 2 meter, lebar $45 \mathrm{~cm}$.

2) Papan pendorong.

3) Kain penutup.

4) Ibu-ibu yang melahirkan Penelitian ini adalah penelitian eksperimen, satu kelompok diberi perlakuan satu kelompok tidak diberi perlakuan pengambilan sampel secara total sampling dari anggota populasi yang sama.

Populasi penelitian ini adalah ibu melahirkan anak pertama tanpa disertai komplikasi di Puskesmas Poncokusumo . Subyek penelitian ini ibu bersalin anak pertama yang sudah di kelompokkan sejumlah 40 ibu bersalin yang di bagi menjadi dua kelompok. Sejalan dengan metode penelitian yaitu eksperimen maka dalam penelitian ini dibagi dalam 2 kelompok yaitu kelompok pertama sebagai eksperimen dan kelompok kedua sebagai kontrol. Yang mana kelompok satu diberi cermin dan kelompok 2 tanpa diberi cermin.

Pengumpulan data menggunakan kuisioner dan lembar observasi pelaksanaan persalinan dengan cermin dan wawancara.
Variabel independen penelitian ini adalah ibu melahirkan dengan menggunakan cermin (X). Variabel dependen penelitian ini adalah lama ibu bersalin kala II (Y) dengan indikator waktu.

Indikator variabel adalah bagaimana menentukan parameter untuk mengukur variabel. Dalam penelitian ini Populasi yang digunakan adalah seluruh ibu yang bersalin di puskesmas Poncokusumo Kabupaten Malang. Pada penelitian ini sampel diambil 40 ibu bersalin di Puskesmas Poncokusumo. Pengambilan sampel menggunakan teknik Total sampling.

Data di kumpulkan dengan menggunakan angket atau kuesioner, observasi dan tes. Dan dianalisa dengan teknik statistik inferensial dengan taraf signifikan 5\% dan taraf kepercayaan (confidence levelsebesar 95\%). Untuk menguji hipotesis tersebut digunakan pendekatan uji-t tidak berpasangan. Untuk mempermudah perhitungan digunakan paket program statistik SPSS.

\section{HASIL}

Berdasarkan tabel 1 diketahui bahwa karakteristik responden berdasarkan fisik terlihat bahwa antara kelompok 1 dan kelompok 2 memiliki karakteristik fisik yang 
hampir sama baik dari segi $\mathrm{TB}, \mathrm{BB}$, kenaikan BB, dan TFU-TBJ.

Tabel 1. Karakteristik Responden Berdasarkan Fisik

\begin{tabular}{|c|c|c|}
\hline $\begin{array}{l}\text { Karakteristik } \\
\text { Responden }\end{array}$ & $\begin{array}{c}\text { Menggunaka } \\
\text { n Cermin } \\
(\text { Kelompok 1) } \\
\%\end{array}$ & $\begin{array}{c}\text { Tanpa } \\
\text { Cermin } \\
(\text { Kelompok 2) } \\
\%\end{array}$ \\
\hline \multicolumn{3}{|l|}{ a. TB (cm) } \\
\hline $145-150$ & 40 & 65 \\
\hline $151-155$ & 45 & 15 \\
\hline $156-160$ & 15 & 20 \\
\hline$>160$ & 0 & 0 \\
\hline \multicolumn{3}{|l|}{ b. BB (kg) } \\
\hline $45-50$ & 15 & 40 \\
\hline $51-55$ & 30 & 20 \\
\hline $56-60$ & 25 & 25 \\
\hline $61-65$ & 10 & 10 \\
\hline $66-70$ & 20 & 5 \\
\hline \multicolumn{3}{|l|}{ c. Kenaikan } \\
\hline BB (kg) & 5 & 5 \\
\hline$<6$ & 95 & 95 \\
\hline $\begin{array}{l}\geq 6 \leq 16 \\
>16\end{array}$ & 0 & 0 \\
\hline d. TFU-TBJ & 5 & 30 \\
\hline $28 \mathrm{~cm} \mathrm{-}$ & 15 & 25 \\
\hline $29 \mathrm{~cm}$ & 15 & 15 \\
\hline $30 \mathrm{~cm}$ & 10 & 5 \\
\hline $31 \mathrm{~cm}-3100$ & 20 & 10 \\
\hline gram & 10 & 15 \\
\hline $\begin{array}{l}32 \mathrm{~cm} \quad- \\
3250 \mathrm{gram}\end{array}$ & & \\
\hline $\begin{array}{l}33 \mathrm{~cm} \quad- \\
3419 \text { gram }\end{array}$ & & \\
\hline 3419 gram & & \\
\hline
\end{tabular}

Berdasarkan Tabel 2 dapat dilihat bahwa rata-rata teriakan ibu / cara mengejan sebagai indikator dari kontraksi antara ibu bersalin yang menggunakan cermin dan tanpa menggunakan cermin berbeda yaitu yang menggunakan cermin 2.00 dan tanpa meggunakan cermin 1.95. Dilihat dari uji $\mathrm{t}$ terlihat bahwa $t_{\text {hitung }}=2.71>\mathrm{t}_{0.05}=1.68$ Dari sini dapat disimpulkan bahwa $\mathrm{H}_{0}$ ditolak dan $\mathrm{H}_{1}$ diterima yaitu $\mu_{1}>\mu_{2}$ artinya artinya bahwa ada perbedaan cara mengejan yang menggunakan cermin dibandingkan dengan ibu bersalin yang tidak menggunakan cermin. Dari observasi dan analisis yang dilakukan oleh peneliti diperoleh hasil bahwa ibu bersalin dengan menggunakan cermin cara mengejan cenderung lebih bagus dibandingkan dnegan yang tidak menggunakan cermin.

Tabel 2 .Nilai Rata-Rata teriakan ibu/ cara mengejan Ibu Untuk Masing-Masing Kelompok Perlakuan

\begin{tabular}{|c|c|c|c|c|c|}
\hline & $\begin{array}{c}\text { Jenis } \\
\text { Persalinan } \\
\end{array}$ & Mean & Sd & $\mathbf{t}_{\text {hit }}$ & $\mathbf{t}_{\mathbf{0 , 0 5}}$ \\
\hline 1 & $\begin{array}{c}\text { Menggunakan } \\
\text { cermin }\end{array}$ & 2.00 & 0.725 & 2.71 & 1.68 \\
\hline 2 & $\begin{array}{r}\text { Tanpa } \\
\text { cermin }\end{array}$ & 1.95 & 0.394 & & \\
\hline
\end{tabular}

Berdasarkan Tabel 3 dapat dilihat bahwa rata-rata frekuensi mengejan sebagai indikator dari kontraksi antara ibu bersalin yang menggunakan cermin dan tanpa menggunakan cermin berbeda yaitu yang menggunakan cermin 2.05dan tanpa meggunakan cermin 1.15. Dilihat dari uji $\mathrm{t}$ terlihat bahwa $\mathrm{t}_{\text {hitung }}=4.456>\mathrm{t}_{0.05}=1.68$. Dari sini dapat disimpulkan bahwa $\mathrm{H}_{0}$ ditolak dan $\mathrm{H}_{1}$ diterima yaitu $\mu_{1}>\mu_{2}$ artinya bahwa ada perbedaan frekuensi mengejan yang menggunakan cermin dibandingkan dengan ibu bersalin yang tidak menggunakan cermin. Dari observasi dan analisis yang dilakukan oleh peneliti diperoleh hasil bahwa ibu bersalin dengan menggunakan cermin frekuensi mengejan 
cenderung lebih banyak dibandingkan dnegan yang tidak menggunakan cermin.

Tabel 3. Nilai Rata-Rata Frekuensi Mengejan Ibu Untuk Masing-Masing Kelompok Perlakuan

\begin{tabular}{llllll}
\hline & Jenis & Mean & Sd & $\mathbf{t}_{\text {hitun }}$ & $\mathbf{t}_{\mathbf{0 , 0 5}}$ \\
& Persalinan & & & $\mathrm{g}$, & \\
\hline $\mathbf{1}$ & Menggunakan & 2.05 & 0.826 & 4.45 & $\mathbf{1 . 6 8}$ \\
& cermin & & & 6 & \\
\cline { 1 - 3 } $\mathbf{2}$ & Tanpa & $\mathbf{1 . 1 5}$ & $\mathbf{0 . 3 6 6}$ & & \\
& cermin & & & & \\
\hline
\end{tabular}

Tabel 4. Nilai Rata-Rata Lama Bersalin Ibu Untuk Masing-Masing Kelompok Perlakuan

\begin{tabular}{llllll}
\hline & Jenis & Mean & (Sd) & $\mathbf{t}_{\text {hitun }}$ & $\mathbf{t}_{\mathbf{0 , 0 5}}$ \\
& Persalinan & & & g, & \\
\hline $\mathbf{1}$ & $\begin{array}{l}\text { Menggunakan } \\
\text { cermin }\end{array}$ & 7.05 & 2.856 & & \\
& & & & 6.46 & $\mathbf{1 . 6 8}$ \\
\cline { 1 - 3 } $\mathbf{2}$ & Tanpa & $\mathbf{1 6 . 1 5}$ & $\mathbf{5 . 6 1 3}$ & & \\
& cermin & & & & \\
\hline
\end{tabular}

Berdasarkan tabel 4 dapat dilihat bahwa rata-rata lama mengejan sebagai indikator dari kontraksi antara ibu bersalin yang menggunakan cermin dan tanpa menggunakan cermin berbeda yaitu yang menggunakan cermin 7.05dan tanpa meggunakan cermin 16.15 Dilihat dari uji t terlihat bahwa $\mathrm{t}_{\text {hitung }}=6.462>\mathrm{t}_{0.05}=1.68$. Dari sini dapat disimpulkan bahwa $\mathrm{H}_{0}$ ditolak dan $\mathrm{H}_{1}$ diterima yaitu $\mu_{1}>\mu_{2}$ artinya bahwa ada perbedaan lama mengejan ibu yang menggunakan cermin dibandingkan dengan ibu bersalin yang tidak menggunakan cermin. Dari observasi dan analisis yang dilakukan oleh peneliti diperoleh hasil bahwa ibu bersalin dengan menggunakan cermin cenderung lebih lama dalam mengejan dibandingkan dengan ibu bersalin yang tidak menggunakan cermin.

Berdasarkan hasil penelitian bila dilihat dari segi waktu yaitu lama persalinan maka terdapat perbedaan yang relative besar antara kelompok 1 dan kelompok 2. Saat ibu bersalin diberi tindakan yaitu kelompok 1 menggunakan cermin dan kelompok 2 tidak menggunakan cermin kemudian diobservasi waktu yang diperlukan dalam persalinan kala II ternyata memiliki selisih waktu yang sangat besar yaitu 9,10 menit. Dimana kelompok 1 membutuhkan waktu 7,5 menit dan kelompok 2 membutuhkan waktu 16,15 menit.

\section{PEMBAHASAN}

Ibu bersalin dipengaruhi beberapa faktor yaitu jalan lahir, janin, power, psikis ibu dan penolong. Psikis ibu ini dipengaruhi dari faktor external dan internal, yang mana faktor external bisa dari suami, orang terdekat, dan keluarga dan faktor internal dorongan dari dirinya sendiri. Dimana dorongan dari dirinya sendiri ini dapat diperoleh ibu melalui melihat langsung proses persalinan yang dialaminya melalui sebuah cermin, sehingga bisa menambah motivasi pada diri ibu untuk mengejan. 
Penelitian ini adalah penelitian eksperimen dimana kelompok 1 diberi perlakuan dan kelompok 2 tidak diberi perlakuan dengan kelompok satu sebagai eksperimen dan kelompok 2 sebagai kontrol. Perlakuan ini berupa persalinan dengan diberi cermin. Setiap kelompok terdiri dari 20 orang, yaitu kelompok 1 melakukan persalinan dengan bantuan cermin dan kelompok 2 melakukan persalinan tanpa bantuan cermin. Variabel yang diamati adalah kontraksi dengan indikator cara mengejan (teriakan) , frekwensi meneran, dan lama bersalin dengan indikator waktu. Dalam setiap persalinan waktu yang dibutuhkan seseorang untuk melahirkan berbeda-beda karena berbagai macam faktor yang mempengaruhinya. Jika frekuensi mengejan lebih banyak dan waktu untuk mengejan lebih lama maka diharapkan waktu yang diperlukan dalam persalinan semakin cepat.

Dari analisa frekuensi dan lama mengejan diatas terlihat bahwa pada persalinan dengan diberi cermin frekuensi mengejan lebih banyak dan waktu untuk mengejan lebih lama. Dari penjelasan diatas bahwa persalinan dengan diberi cermin sangat efektif dalam membatu proses persalinan karena cara mengejan dan frekuensi semakin meningkat ketika persalinan dibantu dengan cermin dan gerakan tubuh seorang ibu semakin tenang, selalu mengikuti anjuran instruktur sehingga mempermudah jalannya proses persalinan.

Selain itu waktu yang diperlukan dalam persalinan juga semakin cepat jika dibandingkan dengan persalinan tanpa menggunakan cermin. Dari sini terlihat bahwa metode ibu persalinan dengan diberi cermin adalah salah satu metode yang dapat diterapkan dalam setiap persalinan dengan tujuan untuk mempermudah dan mempercepat jalannnya persalinan karena dapat membangun semangat pada diri ibu sehingga dorongan dari dalam diri untuk cepat melahirkan semakin tinggi.

Dorongan dari psikis ibu ini timbul saat ibu melihat kepala bayi di depan cermin dimana dengan ibu mengejan kepala akan semakin keluar sehingga dorongan untuk meneran semakin kuat dan semakin banyak frekuensinya. Berdasarkan wawancara yang dilakukan kepada responden diketahui bahwa responden mengatakan sangat senang dengan mengikuti jalannya persalinan karena dapat melihat bayinya sehingga keinginan untuk mengejan semakin meningkat.

\section{KESIMPULAN}

Persalinan dengan menggunakan cermin merupakan metode yang efektif karena dapat mempercepat proses persalinan kala 
II pada ibu primigravida di wilayah Puskesmas Poncokusumo tahun 20018. Dapat dilihat dengan waktu rata-rata yang diperlukan oleh ibu bersalin dengan menggunakan cermin pada saat kala II adalah 7.5 menit dan yang tidak menggunakan cermin rata-rata waktu yang diperlukan adalah 16.15 menit. Metode persalinan dengan menggunakan memiliki efektifitas yang baik karena dapat meningkatkan frekuensi mengejan dan lama waktu dalam mengejan. Halini dibuktikan denngan selisih lamapersalinan antarakelompok kontrol dan kelompok perlakuan dengan nilai selisih 9menit 10 detik lebih cepat kelompok perlakuan atau dengan $\mathrm{t}$ hitung $=6.462>\mathrm{t} 0.05=1.68$.

Metode persalinan dengan menggunakan memiliki efektifitas yang baik karena dapat meningkatkan frekuensi mengejan dan lama waktu dalam mengejan. Halini dibuktikan denngan selisih lamapersalinan antarakelompok kontrol dan kelompok perlakuan dengan nilai selisih 9menit 10 detik lebih cepat kelompok perlakuan atau dengan $\mathrm{t}_{\text {hitung }}=6.462>\mathrm{t}_{0.05}=1.68$.

\section{SARAN}

Berdasarkan hasil penelitian diatas, dikemukakan beberapa saran sebagai berikut:
1. Dalam melakukan pertolongan persalinan khususnya ibu primigravida hendaknya persalinan dengan cermin dapat dijadikan salah satu alternatif pilihan bagi bidan.

2. Bagi praktisi atau mahasiswa lain yang ingin mengadakan penelitian yang sama diharapkan melakukan penelitian dengan jumlah populasi yang banyak untuk memastikan bahwa persalinan dengan menggunakan cermin dapat mempercepat proses persalinan pada kala II ibu primigravida.

\section{REFERENSI}

Ai Nurasiah. (2014). Asuhan Persalinan Normal bagi Bidan. Bandung: Refika Aditama.

Anisah M. (2012). Faktor Faktor yang Berhubungan Dengan Nyeri Persalinan Kala I Fase Aktif Di Ruang Bersalin Rumah Sakit Umum Kabupaten Tanggerang. Retrieved from repository:uinjkt.ac.id/ds pace/biitstream.

Cristine, H. \& Jone, K. (2006). Buku Ajar Konsep kebidanan. Jakarta: EGC.

Hidayat, A. dan S. (2010). Asuhan Kebidanan Persalinan. Yogyakarta: Nuha Medika.

Musrifah U \& A.Azis A.H. (2008). Ketrampilan Dasar Praktek Klinik Untuk Bidan. Jakarta: Salemba Medika.

Sri rejeki, at all. (2014). Tingkat Nyeri Dan Prostaglandin-PadaIbu Inpartu Kala I Dengan Tindakan Counter- Pressure, 9(1). 